
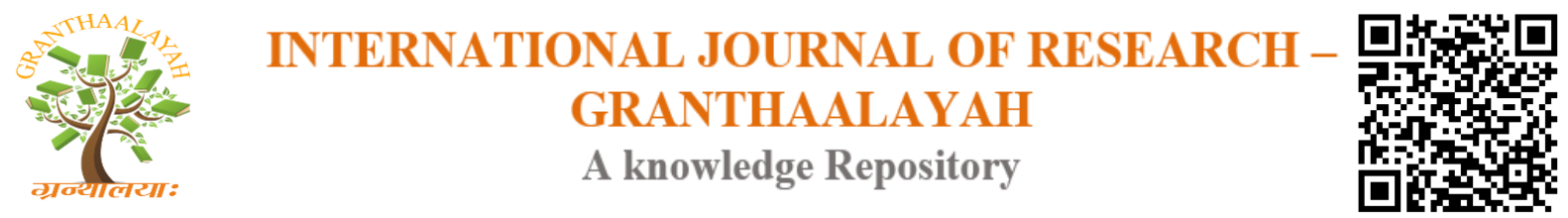

Social

\title{
SUBALTERN IDENTITY OF TRANSGENDER: A PERSPECTIVE OF INDIAN SOCIETY
}

\author{
Sarada P. V. ${ }^{* 1}$ \\ ${ }^{* 1}$ Research Scholar, St Aloysius College, Elthuruth, INDIA
}

DOI: https://doi.org/10.29121/granthaalayah.v4.i9.2016.2541

\section{ABSTRACT}

Transgender is a group whose identity is beyond the notion of conventional gender structures. Mostly they possess male physique and female behavioral traits whose life is complex with conflicts and ridicules. Their existential dilemma revolves around their neglected and unacknowledged sexual identity.

Here the Endeavour is to delve deep into the real sociological positions of transgender in Indian society. i.e., their role definitions played within family and within society. Being transgender is treated as a curse to a family and their existence is relegated to the margin. The marginalised role of transgender could be deciphered by looking at the life of hijras in cities like Bombay and Calcutta.

Keywords:

Transgender, Eunuchs.

Cite This Article: Sarada P. V., "SUBALTERN IDENTITY OF TRANSGENDER: A PERSPECTIVE OF INDIAN SOCIETY” International Journal of Research - Granthaalayah, Vol. 4, No. 9 (2016): 101-104.

\section{INTRODUCTION}

\section{DEFINING TRANSGENDER}

Sexual identity revolves around male and female figures whereas the eunuchs were treated as a rarity. Patriarchal hegemony and female subjugation are the topics of heated discussions for centuries but no such open discussions were occurred in the field of transgender. The expanse of marginalization and humiliation that they suffer in society is beyond even imagination for the mainstream society. Generally the word Transgender or Eunuchs is defined as " a person whose identity does not conform unambiguously to conventional notions of male or female gender roles, but combines or moves between these"'. Transgender is a person with male physique and female behavioral traits which lead to ridicule and chide remarks from his friends and family even. Here the attempt is to analyze the role of Eunuchs in Indian Society. And how the society imprisons the transgender and how their psychological consciousness is discarded. Eunuchs or 
transgender are part and parcel of Indian Society but their existence is neglected by throwing them out of the focus. India is a country with multi cultures, linguistic groups and multi religious people but whatever may be the caste or creed they unacknowledged the existence of a third gender among their group. Sociological demarcations proved the neglection of transgender in the society. Eunuchs were socially marginalized people who wished participation in various genres of life were relegated to the periphery of the Society by addressing them in derogatory terms like 'Hijada' or 'Shikhandi' in India. In Mumbai, the developed city of India, many people belonged to this gender celebrated togetherness and unity by living together. Their sexual identity and Individuality is under the threat of extinguish in a society which stressed on the two biological genders. In Northern part of India, majority of Eunuchs or transgenders celebrated their life by dancing and spending time leisurely in various festivals but their inner psyche is unrevealed.

Unlike the past, when Transgenders were considered as the excluded personality, Transgenders too have realised their own rights and privileges nowadays. In India, Eunuchs were looked at as an underprivileged section. Society defines both male gender and female gender but is silent about the third gender i.e, the Transgenders or the Hijadas. Hijaras have been constantly struggling to find a meaningful and respectable position for themselves. They have always been portrayed as outsiders and excluded. Throughout India, the life of this Transgenders is the same with much humiliating and painful incidents where they were compelled to leave their native place and disguised their body as they wish to live. Thus Hijaras lead a life detached from family and society. The contemporary status of transgender is therefore characterized by their traumatic and violent experiences in the society. Individuality and sexual identity are under threat in such a society which imposes focus mainly upon the masculine and feminine gender. Indian society projects the meaningless existence of eunuchs who lead a life of emptiness and social isolation. Everything seems a burden to eunuchs in society such as family, job, career, education, marriage etc. however hard they had tried, their endeavors are fruitless. Here their existential struggle to find their gender role is really difficult. The reason is that their gender is inexplicable and beyond biological gender.

Treatment of Indian transgender could be viewed in terms of their marginalized and sub-ordinate position. Eunuchs are neither male nor female but contain elements of both. Historical aspects gave evidence for their gender, spiritual, and survival complexities. While looking deeply in the practices of south Asia, realization occurs about how hijras live in well-defined and organized all hijra communities, led by guru. These communities build a zone of comfort for themselves in our society. They sustained themselves over generation by adopting young boys who are rejected by or flee their family of origin. Many among them work as sex workers for survival.

The predicament of Hijras

The word 'Hijra' the Indian usage has traditionally been translated into English as "Eunuchs or hermaphrodite" where the irregularity of the male genitalia is central to the definition. However in general hijras are born with typically male physiology only a few having been born with male inter sex variations.

Most hijras live at the margins of society with low status . The very word hijra is used as a derogatory manner. The Indian Lawyer and author Rajesh Talwar has written a book highlighting the human rights, abuses suffered by the community titled "The Third sex Human 
Rights". There are only meager employment opportunities available to the hijra community. Most of them got their income from extortion, performing at ceremonies (toli), begging (dheengana) or sex work (raarha). Treatment of this third gender in society is really cruel and brutal and occurs in public spaces, police station, prisons and their homes. They face extreme discrimination in health, housing, education, employment, immigration law and any bureaucracy that is unable to place them into male or female gender categories. Indian cities project the life of transgenders who were dancing and begging to find an income. Their dance shows how they were expressing their disguised happy face and merry dance movements. But the veil of happiness is thin and momentary which befalls and honest feelings may capture people's attention. It is generally believed that the transgenders have no feelings, emotions. As their life is unproductive, their dance and songs too are unproductive .Internal rottenness and sterility is reflected in their dance.

\section{INDIAN CONSTITUTIONAL PROVISIONS}

Gender Equality is a constitutional guarantee. To the Indian Social Scenario this right to equality still remains a very distant dream. Widespread inequality is visible in their access to social participation, job opportunities, marriage etc, but during recent years Supreme Court of India acknowledges this transgender or Eunuchs as a third gender and provided them all equal rights and privileges. Supreme Court of India on Tuesday April 15, 2014 created the third gender status for hijras or transgenders. Earlier they were forced to write male or female against their gender. The Supreme Court said absence of Law recognizing hijras as third gender could not be continued as a ground to discriminate them in availing equal opportunities in education and employment. This is for the first time that the gender has got a formal recognition. The Bench said they are part and parcel of the society and the government must take steps to bring them in the main stream of society. On the whole the government and Indian constitution extend all supports for transgenders or Eunuchs to bring them in mainstream.

Justice Radhakrishnan said that transgender people should be treated consistently with other minorities under the law, enabling them to access jobs, healthcare and education. He framed the issue as one of human rights, saying that, "These TGS, even though insignificant in numbers are still human being and therefore they have every right to enjoy their human rights concluding by declaring that

1) Hijras, Eunuchs apart from binary gender, be treated as third gender for the purpose of safeguarding their rights under part III of our constitution and the laws made by the parliament and the state legislature.

2) Transgender person's right to decide their self-identified gender is also up held and the center and state governments are directed to grant legal recognition of their gender identity such as male, female or as third gender.

\section{CONCLUSION}

There are happy signs of change in visibility of Eunuchs in Public spaces, various fields etc. Emergence of transgender in various fields can be seen in modern times. India's first transgender news reader Padmini Prakash reflects her experiences as 'I was disowned by my family when they came to know that I was a transgender. I have faced a lot of discrimination and harassment. 
There has been time when I was not even allowed to walk on the road. Even today, transgender are predominantly found begging on the streets or dancing at private festivals. The only time we get some attention is during the annual koothandavar Temple festival in Koovagam. We fade into oblivion for the rest of the year." These lines show the psyche of a transgender in our society. The gender gap in education is getting closed. The transgender ratio in education and employment is slowly rising. Eunuch's voices are receiving better attention. The new generation is being sensitized on transgender issues. And the emergence of Eunuchs or transgender in advanced fields (Journalists, news readers like Padmini Prakash) create a social awareness about how to treat these third gender and it creates an impression in our psyche how much they are part of our society.

\section{REFERENCE}

[1] Canning, john. ed. 100 Great Books. Great Britain: Richard clay, Ltd, 1967.

[2] Roy Barman, Bhaskar. South Asian Literature Criticism And Poetry. Delhi: Tarun off set, 2011.

[3] www.bbc.com/news/world-asia-india-29357630

[4] Times of india.indiatimes.com

[5] https://en.wikipedia.org/wiki/Transgender

[6] www.apa.org 